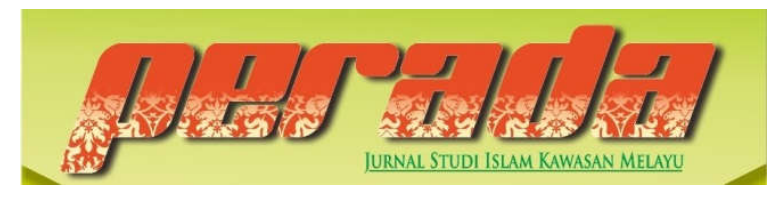

\author{
Perada: Jurnal Studi Islam Kawasan Melayu \\ ISSN 2656-7202 (P) ISSN 2655-6626 (0) \\ Volume 4 Nomor 1, Januari-Juni 2021 \\ DOI: https://doi.org/10.35961/perada.v4i1.345
}

\title{
PENDAMPING TIGA SULTAN, PERAN DAENG KAMBOJA SEBAGAI YDM JOHOR RIAU LINGGA 1697-1777
}

\author{
Dedi Arman \\ Pusat Penelitian Arkeologi Nasional \\ deasutanmakmur79@gmail.com
}

\begin{abstract}
ABSTRAK
Tulisan ini membahas peran Yang Dipertuan Muda (YDM) Daeng Kamboja dalam Kerajaan Johor Riau Lingga. Penelitian ini menggunakan metode penelitian sejarah dan pengumpulan data melalui studi kepustakaan. Daeng Kamboja selama 29 tahun memainkan peran penting dalam Kerajaan Johor Riau Lingga yang mendampingi tiga sultan. Sosoknya yang menentukan pengangkatan (penabalan) Sultan Mahmud Riayat Syah menjadi Sultan Johor Riau Lingga dalam usia masih belia. Kepiawaian Daeng Kamboja dalam bidang pemerintahan, politik dan perdagangan menjadikannya sebagai YDM Kerajaan Johor Riau Lingga yang pertama diakui Belanda. Anak bangsawan Bugis ini dikenal sosok pemberani dan pernah terlibat perang dengan Belanda. Keturunan Daeng Kamboja nantinya banyak berkuasa dalam Kerajaan Johor Riau Lingga, salahsatu putranya bernama Raja Ali nantinya ditunjuk sebagai YDM Kerajaan Johor Riau Lingga V.

This article discusses about the role of Yang Dipertuan Muda (YDM) Daeng Kamboja at Johor Riau Lingga Kingdom. This research used Historical method and library research approach as data collection method. During 29 years, Daeng Kamboja played an important role in accompanying three sultans at Johor Riau Lingga Kingdom. He determined the coronation of Sultan Mahmud Riayat Syah as Sultan in Johor Riau Lingg. At that time, Sultan Mahmud was still young. Daeng Kamboja who had good competencies in government, politic and trading issues made him as the first Yang Dipertuan Muda Riau which acknowledged by the Netherlends. Coming from Bugisnesse family, Daeng Kamboja was known as a brave and involved in the war with Netherlands. His later descendents have a lot of power in Johor Riau Lingga kingdom. One of them is Raja Ali, which had become as the fifth YDM Johor Riau Lingga.
\end{abstract}

Keywords: Role; Daeng Kamboja; Johor Riau Lingga Kingdom. 


\section{PENDAHULUAN}

Orang Bugis melakukan migrasi ke berbagai wilayah nusantara disebabkan beberapa faktor dan periode yang berbeda. Zaman Kerajaan Malaka sedang jayajayanya sebagai pusat perdagangan, Orang Bugis merantau untuk berdagang atau motif ekonomi. Dalam periode selanjutnya, Orang Bugis datang ke belahan barat nusantara tidak lagi karena faktor ekonomi saja, tetapi ada faktorfaktor lainnya. Perpindahan besar-besaran Orang Bugis disebabkan peristiwa Perang VOC di Makassar yang diakhiri Perjanjian Bungaya pada November 1667. Pihakpihak yang kalah dalam perang dan tidak nyaman dengan VOC memilih hijrah dari kampung halaman. Masalah ekonomi juga menjadi salah satu alasan menyebarnya orang Bugis ke berbagai daerah yang disebabkan keterbatasan lahan pertanian di daerah Bone dan Wajo. ${ }^{1}$

Diaspora orang Bugis telah memberikan pengaruh terhadap situasi dan kondisi di daerah rantau, tidak terkecuali di wilayah Kepulauan Riau. Ada struktur baru dalam pemerintahan yang tidak ditemukan di daerah lainnya di nusantara, yakni jabatan Yang Dipertuan Muda atau juga dikenal dengan nama Yamtuan Muda. Masa kini posisinya setara dengan perdana menteri, sementara jabatan sultan disebut Yang Dipertuan Besar (YDB).

Dari Luwu (Sulawesi Selatan), Lima Upu Bersaudara (Daeng Rilaka dan empat anaknya) menyeberangi lautan, sebagian menetap di Siantan. Putra Raja Luwu yang dikenal juga dengan istilah upu-upu itu mengembara hingga ke Kamboja, China, Semenanjung Malaya, dan daerah Pantai Timur Sumatra. Atas jasa-jasa mereka itu, Sultan menganugerahi etnis Bugis jabatan YDM, posisi yang strategis dalam kerajaan setingkat perdana menteri. Posisinya

1 Syahrul Rahmat. Bugis di Kerajaan Melayu: Eksistensi Orang Bugis dalam Pemerintahan Kerajaan Johor Riau Lingga Pahang. Perada: Jurnal Studi Islam Kawasan Melayu, hlm.36 sebagai penasehat sultan, yang juga dijabat secara turun-temurun. Pengangkatan etnis Bugis ke dalam struktur pemerintahan cuma demi akomodasi politik itu terbukti menimbulkan masalah baru di kemudian hari. Pengaturan administrasi pemerintahan yang dualistis di bawah pemerintahan sultan Melayu sebagai YDB dengan YDM asal Bugis, apalagi masingmasing didukung pegawai-pegawai sendiri, mengganggu kenyamanan psikologis para aristokrat Melayu. Banyak dari mereka merasa terlalu diperintah YDM yang etnik Bugis. $^{2}$

Jabatan YDM ada sejak Sumpah Setia atau Persetiaan yang diikrarkan dan dituliskan setelah sultan yang pertama dalam Kerajaan Johor yang ibukotanya di Negeri Riau. Sultan Sulaiman Badrul Alamsyah I melantik atau menabalkan Daeng Marewa yang bergelar Putra Kelana Jaya sebagai YDM Riau I pada tahun 1722. Inilah permulaan bersetia Bugis dengan Melayu seperti yang tersebut dalam suratsurat setia itu adanya," tulis Raja Ali Haji dalam Tubfat al-Nafis. Dokumen sumpah setia pertama yang isinya antara lain menyebutkan bahwa ikatan antara pihak Melayu dan Bugis bagaikan mata hitam dan mata putih yang tidak dapat dipisahkan. Bangsawan Bugis mendapat posisi penting sebagai imbalan atas jasanya dalam mengalahkan Raja Kecik yang ingin berkuasa di Kerajaan Johor.

Sumpah setia Bugis dengan Melayu, dalam perspektif struktural fungsional, tidak lain adalah upaya adaptasi yang dilakukan Orang Bugis di negeri Melayu guna mencapai tujuannya. Bahkan, integrasi dan latensi yang diperlihatkan oleh Bugis dalam pengaruhnya semakin memperkuat tentang sebuah prosesnya untuk menjadi bagian dari Melayu. Ia tidak hanya sekadar menjadi aktor dengan

2 Achmad Syahid, Sufistikasi Kekuasaan pada Kesultanan Riau-Lingga Abad XVIII-XIX M. Jurnal Ulumuna, Volume IX Edisi 16 Nomor 2 JuliDesember 2005, hal.303 
kekuatan struktural saja, melainkan juga memiliki kekuatan fungsional sekaligus. Hal inilah yang membuat Bugis dapat diterima di Tanah Melayu yang menjadikan terjadinya asimilasi dan akulturasi yang mampu melahirkan fenomena sosial dan kebudayaan baru. ${ }^{3}$ Adaptasi sosial dan kebudayaan yang paling tampak antara para pembesar dan bangsawan Bugis dan Melayu adalah melalui perkawinan.

Perkawinan silang antara Melayu dan Bugis menjadi penanda meleburkan darah keturunan dan meleburkan identitas. Tidak hanya pada bangsawan, melainkan juga pada kelompok bawah. Terjadi peleburan identitas yang telah lepas dari pengaruh kesukuannya. Setidaknya itu dibuktikan dengan gelar Raja yang melekat pada setiap anak turunan dari bangsawan Bugis secara patriarki. Gelaran itu dipakai dan disandang hingga saat ini dan menjadi satu gelaran kebangsawanan yang tidak hilang. Orang Bugis secara perlahan justru menanggalkan gelar-gelar kebangsawanan Bugis dan menggunakan gelar-gelar kebangsawanan Melayu. Jika bangsawan Melayu menggunakan gelar Tengku atau Engku, turunan Bugis menggunakan Raja pada nama depan atau gelar kebangsawannya.

Dari 10 orang YDM Johor Riau Lingga, YDM yang paling terkenal adalah Raja Fisabilillah yang tewas di Teluk Ketapang dalam perang melawan Belanda tahun 1784. Tokoh ini diangkat sebagai pahlawan nasional oleh pemerintah Indonesia tahun 1997. Kiprahnya yang heroik sudah banyak ditulis dalam bentuk buku atau pun tulisan lain di jurnal, skripsi atau artikel di media cetak. Selain Raja Haji, sosok YDM Johor Riau Lingga III, Daeng Kamboja juga menarik untuk diungkap. Tidak hanya pemberani melawan Belanda, sosoknya juga mempengaruhi jalannya sejarah Kerajaan Johor Riau Lingga. Daeng Kamboja yang

${ }^{3}$ Ibid, hal. 13 menabalkan Sultan Mahmud Riayat Syah dalam usia 8-9 tahun sebagai Sultan Johor Riau Lingga meski banyak mendapat pertentangan dari internal kerajaan, khususnya Orang Melayu. Ia menjadi YDM dan sekaligus menjalankan tugas dan fungsi sultan karena kondisi sultan yang masih belia.

Penulisan artikel ini mengacu pada sejumlah rumusan permasalahan. Pertama berkaitan dengan latar belakang keluarga Daeng Kamboja. Kedua tentang kiprah Daeng Kamboja selama 29 tahun menjabat sebagai YDM Johor Riau Lingga. Ketiga tentang pasang surut hubungan antara Daeng Kamboja dengan Belanda.

Dalam penulisan Daeng Kamboja ini, ada sejumlah tulisan yang jadi rujukan dan sangat membantu. Beberapa literasi yang berkaitan dengan keterlibatan orang Bugis dalam struktur pemerintahan kerajaan Melayu diantaranya tulisan Sunandar Melacak Hubungan Kesultanan Sambas dan Bugis yang dimuat dalam jurnal Jurnal Khatulistiwa tahun 2014. Artikel ini berusaha menelusuri hubungan yang telah terjadi

antara Bugis dan Kesultanan Sambas. Tulisan lainnya karya Jasni bin Ahmad berjudul Bugis di Kedah: Sebuah Tinjauan Awal 1600-1800. Dalam tulisannya, Jasni menulis upaya orang Bugis untuk mengambil alih pemerintahan di Kerajaan Kedah.

Tulisan lain yang jadi rujukan adalah Syahrul Rahmat, Bugis di Kerajaan Melayu: Eksistensi Orang Bugis dalam Pemerintahan Kerajaan Johor-Riau-Lingga-Pahang dalam Perada: Jurnal Studi Islam Kawasan Melayu Volume 2 Nomor 1, Januari-Juni 2019. Syahrul menyebut kiprah Yang Dipertuan Muda selanjutnya dinilai sangat mendominasi, sehingga secara tidak langsung mengenyampingkan sultan sebagai Yang Dipertuan Besar. Ketidaksenangan dari sebagian Melayu menjadi halangan tersendiri bagi keturunan Bugis, akan tetapi persoalan-persoaln 
tersebut tetap dapat teratasi dengan diplomasi serta pengulangan kembali sumpah setia Melayu Bugis. Dalam perkembangannya, dedikasi para Yang Dipertuan Muda untuk membangun, mengembangkan serta mempertahankan Kerajaan Riau Lingga mulai menghilangkan batas antara Melayu dan Bugis.

Buku yang jadi rujukan dalam penulisan ini, diantaranya A Samad Ahmad, Kerajaan Johor Riau. Dewan Bahasa dan Pustaka, Kementerian Pelajaran Malaysia, 1985. Dalam buku ini diuraikan Sejarah Kerajaan Melayu Johor berawal dari Bukit Siguntang hingga era Kerajaan Johor Riau dibawah Sultan Sulaiman Badrul Alamsyah. Karya lain yang juga sangat membantu dalam penulisan ini adalah Julianti L. Parani, Perantauan Orang Bugis Abad 18. Arsip Nasional Indonesia, 2015. Julianti juga membahas kiprah Orang Bugis dalam Kerajaan Johor Riau Lingga. Beberapa tulisan di atas mengutip dari sejumlah naskah lama, diantaranya Tubfat al Nafis karya Raja Ali Haji dan Belanda di Siak dan Johor, Lukisan SeJarah 1602-1825 karya E Netscher.

\section{METODE PENELITIAN}

Penulisan ini menggunakan metode penelitian sejarah dengan batasan temporal pada abad 18 masa YDM Johor Riau Lingga, Daeng Kamboja berkuasa. Penulisan ini berfokus kepada biografi Daeng Kamboja yang menjabat sebagai YDM Johor Riau Lingga Pahang atau YDM Riau III tahun 1748-1777. Terdapat empat langkah metode sejarah yang wajib ada dalam penulisan sejarah yakni, pertama heuristik. ${ }^{4}$ Heuristik adalah proses

4 Lihat Aulya Meidiana Wahda, et.al. I Mangadacinna Daeng Sitaba Sultan Mabmud Syab Karaeng Pattingngalloang: Raja, Mangkubumi dan Ilmuwan Abad XVII. Attoriolog Jurnal Pemikiran Kesejarahan dan Pendidikan Sejarah Vol. 18 No. 2 (2020): 166-176 menemukan atau mengumpulkan sumbersumber yang akan digunakan untuk merekonstruksi sejarah Pengumpulan data dilakukan dengan dua cara yaitu penelitian kepustakaan dan lapangan dengan cara wawancara. Kedua, kritik sumber adalah melakukan kritik terhadap isi dokumen agar mendapatkan fakta sejarah yang dibutuhkan dalam penulisan ini.

Kritik bertujuan untuk mengecek dengan cara memvalidasi sumber dengan mengecek tulisan tangan, gaya bahasa, dan lain-lain untuk menentukan apakah sumber itu asli atau turunan. Dalam melakukan telaah terhadap sumber sejarah, ada dua hal penting yang perlu dilakukan: otentisitas (penilaian eksternal) dan kredibilitas (penilaian internal).

Ketiga, diperlukan interpretasi di sini, yaitu untuk memastikan keakuratan dan objektivitas yang harus dimiliki oleh penulis (sejarawan) sehingga tidak kepentingan tertentu yang masuk dalam kajian penulisan sejarah ini. Keempat, historiografi sejarah yaitu menyoroti isi, filosofi teoretis penelitian dan penulisan sejarah, membuka metode dokumentasi dan penyajian sejarah, gagasan yang menghubungkan peristiwa, fakta sebagai satu kesatuan yang bermakna, sarana evaluasi dan interpretasi, dan apa yang sangat penting adalah pandangan hidup seorang sejarawan. Pada titik ini, peneliti menggambarkan dan melaporkan hasil penelitian dalam bentuk artikel, mensintesiskan temuan penelitian menjadi satu kesatuan sejarah yang utuh.

\section{PEMBAHASAN}

\section{A. Diaspora Bugis ke Semenanjung Melayu}

Kisah pelayaran Opu Daeng Bersaudara dapat dilihat dalam Kitab Silsilah dan Hikayat dan Sejarah Asli RajaRaja Sebelah Mempawah dan Pontianak dan Matan dan Sambas dan Riau dan Selangor. Kitab Silsilah dan Hikayat 
dan Sejarah Asli Raja Raja Sebelah Mempawah dan Pontianak dan Matan dan Sambas dan Riau dan Selangor" adalah sebuah kitab lama yang disalin oleh fakir H. Abdullah bin Hairudin Peranakan Negeri Jawanah pada tahun 1282 H. Kemudian, kitab silsilah ini selesai ditulis dan dicapkan pada 12 hari Rabiul Akhir sanat 1329 H. Apabila dilihat antara tahun penulisan yaitu tahun $1282 \mathrm{H}^{5}$

Naskah ini menceritakan hikayat dan kisah asal raja raja di Mempawah, Pontianak, Matan, Sambas, Riau dan Selangor. Dalam naskah ini dikisahkan lima Opu bersaudara dari Sulawesi. Dikisahkan bahwa Opu bersaudara ini adalah anak keturunan dari Raja Luwu' yang bernama Siti Malangkei, seorang raja perempuan di Tanah Bugis. Ayah Opu Daeng bersaudara ini adalah Opu Daeng Rilaka yang merupakan keturunan ke-33 dari Raja Luwu' tersebut. Daeng Rilaka memiliki lima anak laki-laki, yaitu Opu Daeng Perani, Opu Daeng Manambon, Opu Daeng Marewah, Opu Daeng Celak dan Opu Daeng Kemasi. Opu Daeng Rilaka pergi ke Topamana beserta kelima anaknya dan menikah dengan Raja Topamana dan mendapatkan anak seorang perempuan bernama Daturawatu. Terjadi suatu kisah seorang penggembala kerbau yang melakukan rutinitas pekerjaannya setiap hari. Pada suatu hari kerbaunya kurang satu, dicari dan dilihatnya bahwa kerbau itu telah mati dan bulunya berguguran. Diamatinya ternyata kerbau itu memakan daun simpur yang ada sebilah besi menyerupai badik. Lalu, besi itu

5. Lisyawati Nurcahyani dan Asnaini. Jalur Jalur Pelayaran dan Pengaruh Kedatangan Lima Opu Daeng Bersaudara di Tanah Melayu dalam Kitab Silsilah serta Hikayat dan Kisah Asal Raja Raja sebelab Mempawah, Pontianak, Matan, Sambas, Riau dan Selangor. (Bandung: CV Media Jaya Abadi, 2019), h. 20-22 diambilnya dan dimasukkannya ke dalam kapua tempat dia menyimpan barang dan pulang ke rumahnya.

Saat bermalam di Makassar Opu Daeng Manambon bermimpi bahwa alat kelamin Opu Daeng Celak keluar menjadi naga dan kepala naga itu menghadap ke barat. Mereka melanjutkan perjalanan ke Betawi untuk menemui saudaranya Opu Daeng Biasa yang telah diberi gelar oleh Belanda sebagai Mayor orang-orang Bugis di Betawi. Mereka saling melepas rindu. Keberadaan mereka di Betawi selama enam bulan saja dan kemudian mereka ingin melanjutkan perjalanan kembali. Opu Daeng Rilaka meminjam uang kepada Opu Daeng Biasa untuk membeli sebuah perahu guna melanjutkan perjalanan mereka ke tanah Melayu. Mereka berlayar menuju Pulau Siantan dan tinggal di rumah Nakhoda Ilang. Opu Daeng Perani dinikahkan dengan puteri Nakhoda Ilang. Selanjutnya, mereka melanjutkan perjalanan ke negeri Malaka. Sesampainya di Malaka mereka mendengar kabar bahwa Raja Culan dari Kamboja saat ini ingin mencari orang yang dapat menjadi tandingannya untuk menyabung ayam, sebab ayam kepunyaannya tidak dapat ditandingi oleh ayam-ayam yang lain. Raja Culan banyak mendapat harta sebab selalu menang dalam menyabung ayam itu. Mendengar kabar ini lalu mereka pun merencanakan membuat dua belas buah peti dengan ukuran panjang satu depa dan lebar setengah depa. Peti-peti itu mereka isi dengan batu, dikunci dan dirantai. Orang lain tidak diperkenankan untuk melihat isi dari petipeti yang menjadi taruhan mereka.

Sampailah mereka ke Kamboja dan diterima dengan baik oleh Raja Kamboja. Mereka menyampaikan maksud mereka hendak mengikuti sabung ayam. Pada saat proses sabung 
akan dimulai, seluruh rakyat Kamboja serta orang-orang Bugis dan Minangkabau yang ada di Kamboja diundang untuk menyaksikan sabung ayam itu sebagai penengah jika terjadi perselisihan di antara mereka. Setelah kesepakatan dibangun para pihak dan disaksikan oleh rakyat Kamboja, proses sabung ayam mulai dilaksanakan. Pada awalnya ayam Raja Culan selalu memenangkan pertandingan itu, tetapi lambat laun ayam Raja Culan pada akhirnya mati juga karena taji kerami yang ada pada ayam Kuri Emas milik Opu Daeng bersaudara telah menggugurkan bulu-bulu ayam Raja Culan. Ayam milik Opu Daeng Rilaka yang keluar sebagai pemenang dalam sabung ayam itu, maka seluruh harta benda dan orang-orang yang dipertaruhkan menjadi milik Opu Daeng Rilaka dan anak-anaknya. Pascakemenangan itu, mereka kembali berlayar ke Siantan, dan sesampainya di Siantan ternyata istri Opu Daeng Perani telah melahirkan seorang anak laki-laki dan diberi nama dengan Daeng Kamboja. Selama menetap di Siantan itu, istri Opu Daeng Perani kembali melahirkan seorang bayi perempuan lagi dan diberi nama Daeng Tijah yang pada akhirnya dijadikan sebagai menantu oleh Raja Alam dari Negeri Siak. Selama di Siantan itu pula Opu Daeng Rilaka meninggal dunia dan tidak diketahui apakah jasadnya dibawa ke Luwu atau tetap dimakamkan di Siantan.

\section{B. Kehadiran Orang Bugis dalam Kerajaan Johor Riau Lingga}

Menurut Rahmat (2019), keterlibatan Bugis dalam ranah politik di kawasan Semenanjung melayu ada dua kasus. Selain Kerajaan Johor, kasus lain juga terjadi di Kerajaan Kedah. Perebutan kekuasaan di kerajaan ini melibatkan Tunku Ngah Putera dengan sultan yang masa itu berkuasa. Tunku Ngah Putera merupakan putera dari Raja Juang Tawa dengan seorang puteri Sultan Kedah. Pergantian pemimpin pascawafatnya sultan tidak berpihak kepada Tunku Ngah Putera, sehingga ia memilih untuk undur diri kembali ke Bugis dan kembali lagi pada tahun 1687 untuk menyerang Kedah. Namun serangan dari Tunku Ngah Putera dapat diredam sehingga ia lari ke Bruas dan kemudian ke Selangor.Selain oleh Tunku Ngah Putera yang memiliki hubungan darah dengan kerajaan Kedah, pemberontakan lain terkait kekuasaan juga terjadi pada tahun 1770 . Pada tahun tersebut terjadi penentangan dari puak (suku) di negeri Kedah yang menentang sultan lantaran usia sultan yang kian uzur dan urusan pemerintahan dijalankan oleh anaknya Tunku Abdullah gelar Yang Dipertuan Muda. Dalam penentangan tersebut, puak meminta pertolongan kepada orang Bugis. Pada 1771 pasukan Bugis sudah sampai di Kuala Sungai Kedah dan melakukan penyerangan, akan tetapi serangan tersebut dapat dilawan karena pihak kerajaan meminta bantuan kepada Inggris untuk menghalau pasukan Bugis yang datang menyerang.

Kondisi Kerajaan Johor berbeda Hal tersebut berawal setelah meninggalnya Sultan Johor, Sultan Mahmud pada 1699 d Kota Tinggi Johor. Disebabkan ketiadaan pengganti, maka pada awal September 1699 bendahara kerajaan yang waktu itu dipegang oleh Tun Abdul Jalil naik untuk mengisi posisi sultan dengan gelar Sultan Abdul Jalil Riayat Syah. Setelah tampuk pemerintahan dipegang oleh Sultan Abdul Jalil Riayat Syah, maka selanjutnya muncullah Raja Kecik yang mengaku sebagai keturunan dari Sultan Mahmud Syah II. Dalam perjalanan untuk merebut kembali kekuasaan dari Sultan Riayat Syah, Raja 
Kecik bertemu dengan Opu Daeng Bersaudara dan meminta mereka untuk bergabung, dengan kesepakatan apabila upaya mereka untuk merebut kekuasaan berhasil, maka Daeng Perani akan diangkat sebagai YDM. Setelah pertemuan yang berlangsung di Muara Sungai Johor itu, maka Opu Daeng Bersaudara berangkat menuju Langat yang merupakan tempat bermukim orang Bugis di wilayah Johor. Selain dari orang Bugis, Raja Kecik juga mendapat bantuan dari daerah Kuala Johor dan Singapura yang mana dulunya wilayah tersebut merupakan basis pendukung Sultan Mahmud Syah. Tanpa menghiraukan kesepakatan dengan Opu Daeng Bersaudara, Raja Kecik

Pada 21 Maret 1717, Raja Kecik berhasil menaklukkan Johor dan diangkat menjadi sultan dengan gelar Sultan Abdul Jalil Rahmat Syah, sementara Sultan Abdul Jalil yang sebelumnya memerintah dijadikan bendahara kerajaan. Keterlibatan orang Bugis, yang dalam hal ini adalah anakanak dari Daeng Rilaka berlanjut ketika adanya upaya merebut kekuasaan dari Abdul Jalil Rahmat Syah oleh anak Sultan Abdul Jalil yang saat itu sudah kembali menjabat sebagai bendahara kerajaan. Dalam beberapa sumber disebutkan Tengku Sulaiman Sultan Abdul Jalil ingin kembal merebut tahta kerajaan lantaran tidak terima karena merasa dipermainkan oleh Sultan Abdul Jalil Rahmat Syah.

Netscher dalam karyanya juga menyoroti peranan Orang Bugis dalam Kerajaan Johor Riau Lingga. Orang Bugis Daeng Perani, Daeng Marewa dan Daeng Celak membantu Sultan Sulaiman menaiki tahta sebagai sultan tanggal 22 Oktober 1721. Kondisi ini menyebabkan Sultan Sulaiman sulit menghindari pengaruh Bugis dalam menjalankan kekuasaannya. Keterikatan antara pihak Bugis dengan Sultan Sulaiman makin erat dengan adanya perkawinan usai Sultan Sulaiman naik tahta. Daeng Marewa kawin dengan Encik Ayu, janda Sultan Mahmud, Daeng Perani nikah dengan Tengku Tengah, saudara Sultan Sulaiman dan Daeng Celak menikah dengan saudara Sultan Sulaiman yang lain, Tengku Mandak. ${ }^{6}$

Tabel Silsilah Yang Dipertuan Muda Johor Riau Lingga

\begin{tabular}{|c|c|c|c|}
\hline $\begin{array}{l}\text { Yang } \\
\text { Dipertuan } \\
\text { Muda }\end{array}$ & Pemerintahan & $\begin{array}{l}\text { Nama atau } \\
\text { gelar }\end{array}$ & $\begin{array}{l}\text { Catatan dan } \\
\text { peristiwa } \\
\text { penting }\end{array}$ \\
\hline I & $1722-1729$ & $\begin{array}{l}\text { Daeng } \\
\text { Marewah }\end{array}$ & $\begin{array}{l}\text { Wafat di } \\
\text { Sungai Baharu, } \\
\text { Ulu Riau dan } \\
\text { dimakamkan } \\
\text { di sana }\end{array}$ \\
\hline II & $1728-1745$ & $\begin{array}{l}\text { Daeng } \\
\text { Celak }\end{array}$ & $\begin{array}{l}\text { Wafat di Pulau } \\
\text { Petung dan } \\
\text { dikuburkan di } \\
\text { Hulu Sungai } \\
\text { Riau (Pulau } \\
\text { Bintan) }\end{array}$ \\
\hline III & $1745-1777$ & $\begin{array}{l}\text { Daeng } \\
\text { Kamboja }\end{array}$ & $\begin{array}{l}\text { Dimakamkan } \\
\text { di Kampung } \\
\text { Bugis, } \\
\text { Tanjungpinang }\end{array}$ \\
\hline IV & $1777-1784$ & $\begin{array}{l}\text { Raja Haji } \\
\text { Fisabilillah }\end{array}$ & $\begin{array}{l}\text { Gugur dalam } \\
\text { pertempuran } \\
\text { melawan } \\
\text { Belanda di } \\
\text { Teluk } \\
\text { Ketapang. } \\
\text { Dikuburkan di } \\
\text { Penyengat }\end{array}$ \\
\hline V & 1784- 1806 & $\begin{array}{l}\text { Raja Ali } \\
\text { atau } \\
\text { Marhum } \\
\text { Pulau } \\
\text { Bayan }\end{array}$ & $\begin{array}{l}\text { Beliau } \\
\text { meninggal di } \\
\text { Pulau Bayan, } \\
\text { didepan } \\
\text { Gudang } \\
\text { Minyak dan } \\
\text { dikuburkan di } \\
\text { Tanjung } \\
\text { Unggat }\end{array}$ \\
\hline VI & 1806- 1832 & Raja Ja'far & $\begin{array}{l}\text { Meninggal di } \\
\text { Daik Lingga } \\
\text { dan dibawa } \\
\text { dan }\end{array}$ \\
\hline
\end{tabular}

${ }^{6}$ E Nestcher. Belanda di Johor dan Siak 16021865, Lukisan Sejarah. (Pekanbaru: Yayasan Arkeologi dan Sejarah Bina Pusaka), h. 95-96. 


\begin{tabular}{|l|l|l|l|}
\hline & & & $\begin{array}{l}\text { dimakamkan } \\
\text { di Penyengat. }\end{array}$ \\
\hline VII & $1832-1844$ & $\begin{array}{l}\text { Raja Abdul } \\
\text { Rahman } \\
\text { bin Raja } \\
\text { Jaafar }\end{array}$ & $\begin{array}{l}\text { Wafat dan } \\
\text { dimakamkan } \\
\text { di Kampung } \\
\text { Bulang, Pulau } \\
\text { Penyengat }\end{array}$ \\
\hline VIII & $1844-1857$ & $\begin{array}{l}\text { Raja Ali bin } \\
\text { Raja Ja'far }\end{array}$ & $\begin{array}{l}\text { Wafat dan } \\
\text { dimakamkan } \\
\text { di Pulau } \\
\text { Penyengat }\end{array}$ \\
\hline IX & $1857-1858$ & $\begin{array}{l}\text { Raja Haji } \\
\text { Abdullah }\end{array}$ & $\begin{array}{l}\text { Wafat dan } \\
\text { dimakamkan } \\
\text { di Penyengat }\end{array}$ \\
\hline X & $1858-1899$ & $\begin{array}{l}\text { Raja } \\
\text { Muhammad } \\
\text { Yusuf al- } \\
\text { Ahmadi }\end{array}$ & $\begin{array}{l}\text { Wafat dan } \\
\text { dimakamkan } \\
\text { di Daik, } \\
\text { Lingga }\end{array}$ \\
\hline
\end{tabular}

Sumber : Kumpulan Data Tim Penulis (2021)

\section{Latar Belakang Kehidupan Daeng Kamboja}

Daeng Kamboja dari namanya saja orang bisa menebak asal usulnya. Daeng Kamboja nenek moyangnya berasal dari Kerajaan Luwuk yang hari ini secara administrasi masuk dalam wilayah Provinsi Sulawesi Selatan. Daeng Kamboja keturunan Lamadusalad, Raja Bugis yang pertama masuk Islam. Lamadusalad memiliki tiga anak laki-laki. Anak pertama bernama Upu Pajung yang menjadi raja negeri Luwuk. Anak kedua bernama Upu Tanderi Daeng Rilaka. Keturunan Daeng Rilaka inilah yang mengembara ke bagian barat nusantara dan menjadi raja disejumlah kerajaan, seperti Johor Riau, Selangor, Siak dan juga Singapura, termasuk juga di Kalimantan. ${ }^{7}$ Daeng Rilaka ini memiliki lima anak laki-laki dan satu orang anak perempuan, yakni Upu Daeng Perani, Daeng Menambun, Daeng Marewa, Daeng Celak dan

7 A. Samad Ahmad. Kerajaan Johor Riau. (Kualalumpur: Dewan Bahasa dan Pustaka, Kementerian Pelajaran Malaysia), h.1
Daeng Kemasi. Anak perempuan Daeng Rilaka bernama Ratu Ruatur.

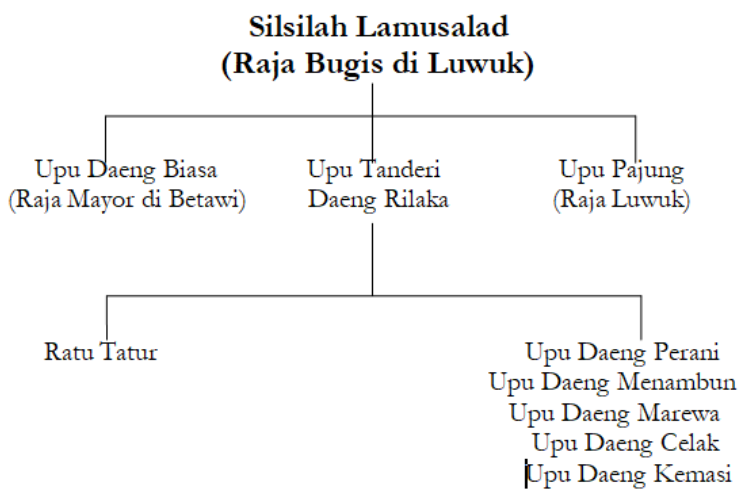

Sumber: Samad (1985)

Anak tertua Daeng Rilaka bernama Daeng Perani yang menikah dengan saudara perempuan Sultan Sulaiman Badrul. Alamsyah I yang bernama Tengku Tengah. Selain itu ia juga menikah anak perempuan Nahkoda Alang, tokoh Bugis yang ada di Siantan, daerah kepulauan di gugusan Pulau Tujuh Kepulauan Riau.

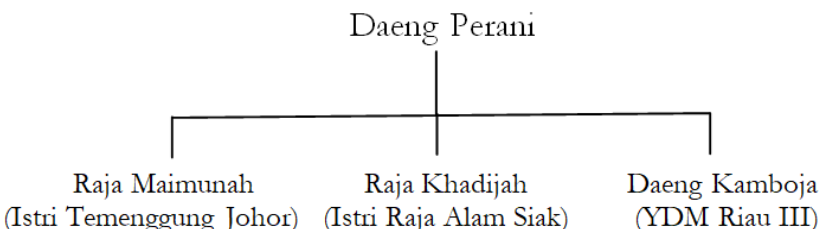

Sumber: Samad (1985)

Daeng Kamboja lahir di Siantan, gugusan Pulau Tujuh, Kepulauan Riau tahun 1697. Embel embel nama Kamboja kisahnya cukup menarik. Berawal dari Opu Daeng bersaudara, Daeng Rilaka dan lima anaknya hijrah dari Sulawesi ke nusantara bagian barat dan singgah di Siantan. Di sana mereka tinggal di rumah Nahkoda Alang atau Karaeng Abdul Malik. Mereka bekerjasama dalam bidang perdagangan. Daeng Perani dinikahkan dengan anak Nahkoda Alang ini. Dari Siantan, mereka pergi ke Kamboja untuk aktivitas perdagangan. Di sana 
mereka bertemu Raja Chulan yang disebut berasal dari Minangkabau. Pihak Bugis dengan Raja Minangkabau ini terlibat pertarungan sabung ayam yang dimenangkan kelompok Opu Daeng Bersaudara. Dari Kamboja, mereka kembali ke Siantan. Saat kembali ke Siantan, istri Daeng Perani melahirkan seorang anak laki-laki. Dalam mengenang kemenangan mereka di Kamboja, anak laki-laki itu diberi nama Daeng Kamboja.

Daeng Kamboja menikah dengan Raja Fatimah yang merupakan anak dari Daeng Marewa yang merupakan pamannya. Perkawinan ini menghasilkan Sembilan anak, yakni Raja Perak yang kemudian menikah dengan Raja Haji Fisabilillah. Kedua, Raja Khadijah. Ketiga, Raja Andak. Keempat Raja Sa'id, kelima, Raja Aisyah. Keenam, Raja Endut. Adapun Raja Utih adalah istri Raja Ismail, menantu Raja Sa'id, menantu Daeng Merewah. Tujuh, Raja Ali, Marhum Pulau Bayan. Kedelapan, Raja Abdul Samad; dan raja kesembilan Usuh. Anak pertama sampai ketujuh satu ayah dan satu ibu. Sementara, Raja Usuh dan Raja Abdul Samad anak dari gundik. ${ }^{9}$

\footnotetext{
8 Cerita tentang perjalanan Opu Daeng Bersaudara ke Kamboja dan pertarungan sabung ayam dengan Raja Chulan ditulis dalam banyak naskah, seperti Tuhfat al Nafis karya Raja Ali Haji. Selain itu, juga diceritakan dalam karya E Netscher, Belanda di Johor dan Siak 1602-1865, Lukisan Sejarah. Wan Ghalib (Penerjemah).

${ }^{9}$ A. Samad, h.14
}

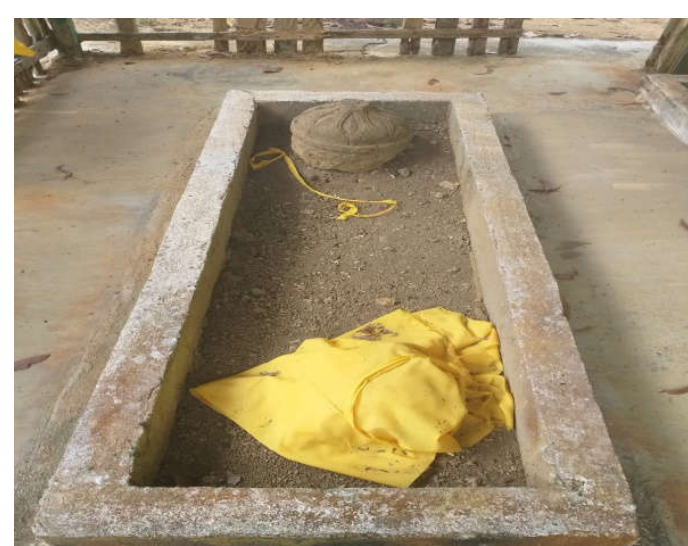

Makam Daeng Kamboja di Kampung

Kuda Pasir, Kampung Bugis

Sumber: Foto Penulis 2021

Daeng Kamboja meninggal tahun 1777 dan makamnya mengundang perdebatan karena dalam naskah seperti Tuhfat al Nafis tidak disebutkan letak makamnya. Hal ini berbeda dengan Makam Daeng Marewa dan Daeng Celak, serta makam YDM Johor Riau Lingga yang lainnya. Makamnya di Kampung Kuda Pasir, Kelurahan Kampung Bugis, Kota Tanjungpinang masih ada yang meragukan kebenarannya. Hal yang cukup mengundang kontroversi adalah kekeliruan Dinas Pendidikan dan Kebudayaan Kota Tanjungpinang yang melakukan pemeliharaan makam tahun 2013. Makam yang dikonservasi adalah makam keluarga Daeng Kamboja. Makam Daeng Kamboja yang berada dalam satu komplek tidak dikonservasi. Kekeliruan ini diinformasikan Raja Malik Afrizal, keturunan Bugis yang tinggal di Penyengat. Sejak tahun 1980an, Malik mengaku sering ziarah ke Makam Daeng Kamboja ini. Pendapat Malik ini dibenarkan Surjadi, mantan Kadis Kebudayaan dan Pariwisata Kota Tanjungpinang. Nisan Makam Daeng Kamboja katanya sama dengan nisan Makam Daeng Celak di Hulu Riau. Nisannya ada gambar bunga teratai. 


\section{Kiprah Daeng Kamboja sebagai YDM Johor Riau Lingga}

Daeng Celak yang menjabat YDM Johor Riau Lingga II meninggal dunia 1158 Hijriah atau 19 Mei 1745 yang membuat gempar kerajaan Johor Riau. Kerajaan Johor Riau berkabung selama 40 hari. Atas kesepakatan pihak Bugis dan Melayu, ditunjuklah Daeng Kamboja sebagai YDM Johor Riau Lingga III penganti Daeng Celak. Daeng Kamboja yang merupakan anak Daeng Perani lebih patut dibandingkan Raja Haji yang saat itu berusia masih terlalu muda. Atas permintaan dari Sultan Johor Riau, Sulaiman Badrul Alamsyah ini, Daeng Kamboja meminta waktu untuk berunding dengan saudara-saudaranya dari pihak Bugis yang ada di Selangor. Barulah tahun 1748, Daeng Kamboja balik ke Riau (Hulu Riau) dan dilantik sebagai YDM Riau III tanggal 11 Maret $1748 .{ }^{10}$

Pada zaman YDM Johor Riau Lingga III, Daeng Kamboja, kondisi Kerajaan Johor Riau yang begitu makmur di era Daeng Celak, kondisinya berubah. Kemakmuran Kerajaan Johor Riau terganggu karena adanya konflik internal antara pihak Bugis dan Melayu. Hal ini bermula saat Sultan Sulaiman membuat perjanjian dengan Gubernur Belanda di Melaka bulan Januari 1746. Dalam perjanjian itu, Belanda berjanji mengembalikan daerah jajahan yang telah hilang kepada Sultan Sulaiman. Sebagai kompensasi, Belanda diperbolehkan memborong biji timah di Selangor, Kelang dan Linggi. ${ }^{11}$ Sultan mengirim surat kepada Daeng

${ }^{10}$ Lihat Virginia Matheson Hooker. Tuhfat al Nafis karangan Raja Ali Haji. (Kualalumpur: Yayasan Karyawan dan Dewan Bahasa dan Pustaka, 1998), h.121-122

11 Shaharom Husain. Sejarah Johor, Kaitannya dengan Negeri Melayu. (Kualalumpur: Fajar Bakti SDN.BHD, 1995), h. 37
Kamboja dan petinggi Bugis Raja Tua Kelang dan Raja Lumun terkait perjanjian dengan Belanda. Daeng Kamboja dan pembesar Bugis marah besar dengan tindakan sultan ini karena penambangan timah di Selangor, Kelang dan Linggi selama ini dikuasai pihak Bugis sejak era Daeng Perani.

Konflik memuncak setelah Belanda yang dibantu Sultan Mansur Shah dari Trengganu yang merupakan menantu Sultan Sulaiman menyerang orang Bugis di Linggi. Daeng Kamboja dan saudara-saudaranya pada bulan Oktober 1756 menyerang Belanda di Melaka. Sultan Sulaiman berpihak kepada Belanda dan pada bulan Desember 1757, ia menyerahkan Linggi kepada Belanda dengan tujuan agar perlawanan Daeng Kamboja dan kelompok Bugis bisa dipadamkan. Pertentangan antara Belanda dan Daeng Kamboja berakhir melalui perjanjian tanggal 1 Januatri 1758. Peperangan antara pihak Bugis dan Belanda merugikan kedua belah pihak karena berdampak pada perekonomian kawasan Johor Riau hingga Selangor. Tidak hanya itu, Raja Haji Fisabilillah yang menjadi Kelana Jaya atau jabatan calon YDM menderita luka parah dalam perang dengan Belanda di Linggi. 12

Buyong Adil (1991) dalam tulisannya memaparkan Sultan Sulaiman Badrul Alamsyah I meninggal di Hulu Riau pada usia lebih kurang 60 tahun tahun 1760. YDM Daeng Kamboja dan Raja Haji selaku Kelana Jaya (Calon YDM) masih di Rembau. Putra almarhum, Raja Abdul Jalil Raja di- 38 Baroh yang telah ditentukan bakal menggantikan almarhum sedang di Selangor. Sekitar lima bulan kemudian, Sultan Abdul Jalil yang

${ }^{12}$ Ibid, hl.38 
berada di Selangor meninggal mendadak. Jenazahnya disiapkan di Selangor dan dibawa ke Pedas (Rembau), tempatnya YDM Daeng Kamboja dan Raja Haji Fisabilillah yang saat itu menjabat Kelana atau calon YDM).

Dari Pedas, dengan prosesi adat, jenazah dibawa YDM Daeng Kamboja dan Raja Haji dalam rombongan yang besar. Ada 45 buah perahu (kapal) saat balik ke Riau Februari 1761. Di Riau, rombongan disambut secara adat. Menurut Buyung Adil, usai kematian sultan, YDM Daeng Kamboja bersama petinggi Bugis melantik Raja Ahmad, putra sulung almarhum, menjadi Yang Dipertuan Besar, Sultan Riau-LinggaJohor-Pahang dan daerah taklukannya, dan digelar Sultan Ahmad Riayat Syah. Pada masa itu, usia baginda lebih kurang sembilan tahun dan adindanya, Raja Mahmud, masih kecil. Selepas itu, barulah jenazah almarhum Sultan Abdul Jalil dimakamkan di pemakaman ayahandanya, Marhum Batangan (Sultan Sulaiman Badrul Alamsyah). Sahdan, tidak lama selepas itu ibunda Sultan Ahmad,Engku Putih binti Daeng Celak mangkat pula. Sehingga Raja Mahmud dan kakandanya Sultan Ahmad Riayat Syah menjadi yatim piatu. Akibatnya, keduanya berada dalam pengasuhan keluarga suku Melayu di Kampung Bulang dan dalam tanggungjawab Daeng Kamboja dan Raja Haji. Sultan Ahmad pada waktu itu baru berumur delapan atau sembilan tahun, tetapi tak mendapat asuhan yang diperlukan dari ibundanya, Engku Putih, karena ibundanya meninggal beberapa minggu setelah suaminya Tengku Besar Abdul Jalil wafat. Engku Putih, sewaktu suaminya berada di Selangor pada akhir 1760, telah melahirkan putera kedua yang diberi nama Raja Mahmud. Ternyata, Raja Ahmad tak berumur panjang, dan Raja
Mahmud, adiknya, masih bayi dan masih digendong ketika dilantik Daeng Kamboja menjadi sultan.

Dari peristiwa ini menunjukkan betapa besar peranan seorang Daeng Kamboja yang tidak hanya menambalkan sultan, tetapi juga menjalankan fungsi dan tugas sultan sampai Sultan Mahmud Riayat Syah dewasa. Posisinya dalam kerajaan tidak tergantikan sampai meninggal 1777. Posisinya digantikan Raja Haji Fisabilillah, YDM Johor Riau IV yang menjabat tidak terlalu lama karena tewas dalam perang melawan Belanda di Teluk Ketapang. Daeng Kamboja berkuasa selama 29 tahun, sementara Raja Haji Fisabilillah menjabat YDM hanya selama tujuh tahun dari tahun 1777-1784.

\section{KESIMPULAN}

Daeng Kamboja putra bangsawan Bugis, Daeng Perani yang lahir di Siantan, gugusan Pulau Tujuh, Anambas. Ia diangkat sebagai Yang Dipertuan Muda (YDM) Johor Riau Lingga III mengantikan Daeng Celak tahun 1948 dan berkuasa hingga tahun 1777. Selama menjabat, Daeng Kamboja figur yang sangat kuat dibidang politik dan juga pemberani. Ia pernah berkonflik dengan Sulaiman Badrul Alamsyah I yang notabene adalah orang yang mengangkatnya sebagai YDM Johor Riau Lingga. Berbagai upaya dilakukan sultan dan didukung Belanda dalam menggulingkan Daeng Kamboja sebagai YDM namun tidak berhasil. Daeng Kamboja dibantu Raja Haji selaku Kelana Jaya pernah terlibat perang sengit dengan Belanda di Lingga. Perang mengakibatkan Raja Haji terkena tembakan di bagian pinggul namun Belanda tidak bisa mengalahkan Daeng Kamboja sampai kedua belah pihak menandatangi surat perjanjian damai dan kerjasama. Daeng 
Kamboja yang meninggal tahun 1777 mempunyai sembilan anak. Satu orang diantaranya menjabat YDM Johor Riau Lingga V, Raja Ali.

Makam Daeng Kamboja berada di Kampung Kuda Pasir, Kelurahan Kampung Bugis, Kota Tanjungpinang. Meskipun ada pihak yang meragukan kebenarannya. Selain itu, juga ada keliruan dalam program konservasi atau pemeliharaan makam yang dilakukan Pemko Tanjungpinang tahun 2013. Makam yang dipugar bukanlah makam Daeng Kamboja melainkan makam anggota keluarganya.[]

\section{DAFTAR PUSTAKA}

Ahmad, A. Samad. Kerajaan Johor Riau. (Kualalumpur: Dewan Bahasa dan Pustaka, Kementerian Pelajaran Malaysia)

Hooker, Virginia Matheson. Tubfat al Nafis karangan Raja Ali Haji. (Kualalumpur: Yayasan Karyawan dan Dewan Bahasa dan Pustaka, 1998).

Husain, Shaharom. Sejarah Johor, Kaitannya dengan Negeri Melayu. (Kualalumpur: Fajar Bakti SDN.BHD, 1995).

Malik, Abdul. Sejarah Kejuangan dan Kepablawanan Sultan Mabmud Riayat Syah Yang Dipertuan Besar Kerajaan Riau Lingga Johor Pahang (17611812). (Lingga: Pemprov KepriPemkab Lingga, 2012).

Nestcher, E. Belanda di Johor dan Siak. $1602-$ 1865, Lukisan Sejarah. (Pekanbaru: Yayasan Arkeologi dan Sejarah Bina Pusaka)

Nurcahyani, Lisyawati dan Asnaini. Jalur Jalur Pelayaran dan Pengaruh Kedatangan Lima Opu Daeng Bersaudara di Tanab Melayu dalam Kitab Silsilah serta Hikayat dan Kisah Asal Raja Raja sebelah Mempawah, Pontianak, Matan, Sambas, Riau dan Selangor. (Bandung: CV Media Jaya Abadi, 2019).

Rahmat, Syahrul, "Bugis di Kerajaan Melayu: Eksistensi Orang Bugis dalam Pemerintahan Kerajaan Johor Riau Lingga Pahang'. Perada: Jurnal Studi Islam Kawasan Melayu, Vol.2, No. 1 (2019). DOI https://doi.org/10.35961/perada. v2i1.25

Syahid, Achmad, 'Sufistikasi Kekuasaan pada Kesultanan Riau-Lingga Abad XVIII-XIX M', Jurnal Ulumuna, Vol. 9, No. 2 (2005), DOI: 
https://doi.org/10.20414/ujis.v9i2 .489

Wahda, et.al, 'I Mangadacinna Daeng Sitaba Sultan Mahmud Syah Karaeng Pattingngalloang: Raja, Mangkubumi dan Ilmuwan Abad XVII', Attoriolog: Jurnal Pemikiran Kesejarahan dan Pendidikan Sejarah Vol. 18, No. 2 (2020): 166-176. 